\title{
RENCANA PENGELOLAAN KAWASAN WISATA PULAU TIDUNG, KELURAHAN PULAU TIDUNG, KECAMATAN KEPULAUAN SERIBU SELATAN
}

\author{
Garry Jeremiah Anthony Rey ${ }^{1)}$, Suryono Herlambang ${ }^{2)}$
}

1)Program Studi S1 PWK, Fakultas Teknik, Universitas Tarumanagara, garry.354150023@stu.untar.ac.id 2)Program Studi S1 PWK, Fakultas Teknik, Universitas Tarumanagara, suryonoh@ft.untar.ac.id

\begin{abstract}
Abstrak
Kawasan Wisata Pulau Tidung adalah objek wisata alam yang berada di Kelurahan Pulau Tidung, Kecamatan Kepulauan Seribu yang menawarkan Pantai dan Keindahan bawah laut sebagai daya tarik Pariwisata Pulau Kecil. Selain itu jumlah homestay yang banyak merupakan pembeda Pulau Tidung dengan Pulau-Pulau Kecil lainnya di Kepulaun seribu. Jumlah wisatawan yang tinggi tiap tahunnya menjadi penanda bahwa Kawasan Wisata Pulau Tidung menjadi salah satu opsi masyarakat dalam menghabiskan waktu berlibur yang ada. Seiring dengan bertambah banyaknya wisatawan maka perlu dilakukaan perbaikan dan peningkatan kualitas terhadap manajemen dan juga kondisi fisik fasilitas yang ada sehingga pengelolaan pulau kecil dapat terjaga. Virtual Hotel Operator merupakan suatu sistem yang bisa menjadi jawaban dalam pengelolaan homestay yang ada. Selain itu, masih kurangnya keterlibatan masyarakat secara langsung dalam pengelolaan Pulau yang ada juga menjadi perhatian yang serius. Tujuan dari penelitian ini yaitu mengetahui sistem pengelolaan yang ada di Pulau Kecil khususnya Pulau Tidung, persepsi dan preferensi pengunjung mengenai Kawasan Wisata serta mengusulkan rencana pengelolaan Kawasan Wisata Pulau Tidung. Untuk mencapai tujuan tersebut dilakukan beberapa analisis yaitu : analisis kebijakan, analisis kondisi fisik dan pengelolaan, analisis persebaran, kondisi dan pengelolaan akomodasi, analisis persepsi dan preferensi pengunjung, analisis daya dukung dan analisis rencana dan strategi pengelolaan. Analisis yang dilakukan menggunakan alat analisis yaitu deksriptif, SWOT, perhitungan daya dukung, skala likert dan diagram cartesius.
\end{abstract}

Kata Kunci: Keterlibatan masyarakat; Pengelolaan pulau kecil; Pengelolaan homestay; Virtual hotel operator

\begin{abstract}
Tidung Island Tourism Area is a natural tourist attraction located in the Tidung Island Village, Seribu Islands District which offers Beach and Underwater Beauty as the attraction of Small Island Tourism. In addition, the large number of homestays is the difference between Tidung Island and other small islands in Kepulaun Thousand. The high number of tourists each year is a marker that Tidung Island Tourism Area is one of the options for the community to spend their vacation time. Along with the increasing number of tourists, it is necessary to repair and improve the quality of management and also the physical condition of existing facilities so that small island management can be maintained. Virtual Hotel Operator is a system that can be an answer in managing existing homestays. In addition, there is still a lack of direct community involvement in the management of the Island which is also a serious concern. The purpose of this study is to find out the management system in Small Island, especially Tidung Island, visitors' perceptions and preferences regarding the Tourist Area and propose a plan for managing the Tidung Island Tourism Area. To achieve these objectives, several analyzes were carried out, namely: policy analysis, physical conditions and management analysis, distribution, conditions and management of accommodation analysis, perception and visitor preferences analysis; carrying capacity analysis management plans and strategies analysis. These analysis were done using descriptive analysis tool, SWOT, calculation of carrying capacity, likert scale and cartesius.
\end{abstract}

Keywords: community involvement; homestay management; small island management; Virtual Hotel Operator 


\section{PENDAHULUAN}

Kepulauan Seribu merupakan daerah kepulauan terdekat dengan Ibukota Jakarta. Posisi yang sangat strategis ini dapat dimanfaatkan untuk menggali berbagai potensi agar dapat dimanfaatkan dengan baik. Selain di bidang investasi perikanan, tambang dan pengembangan daerah tujuan wisata, wisatawan yang datang ke Kepulauan seribu, juga turut meberi andil dalam pengembangan kawasan Kepulauan Seribu. Kepulauan Seribu merupakan wilayah yang meliputi daratan dan lautan. Luas Kepulauan Seribu mencapai 11,81 Km2 dengan persebaran pulau kecilnya sejumlah 110 pulau yang meliputi 11 pulau permukiman , 48 pulau wisata ( resort ) dan 53 pulau tak berpenghuni lain ( sumber dari BPS Kepulauan Seribu ).

Kepulauan Seribu sendiri termasuk kedalam wilayah Kabupaten Adminstasi Kepulauan Seribu dan merupakan wilayah adminstrasi yang memiliki luas paling kecil dibandingkan wilayah administrasi lainnya di Jakarta, yaitu hanya memiliki luas daratan sekitar 8,7 km2. Selain itu, Kabupaten Administrasi Kepulauan Seribu merupakan satu-satunya Kabupaten Adminstrasi yang ada di DKI Jakarta. Kabupaten Administrasi Kepulauan Sribu memiliki 2 kecamatan, yaitu Kecamatan Kepulauan Seribu Utara dan Kecamatan Kepulauan Seribu Selatan serta dimasingmasing Kecamatan terdiri dari 3 Kelurahan yaitu Kelurahan Pulau Kelapa, Kelurahan Harapan dan Kelurahan Panggang ( Kecamatan Kepulauan Seribu Utara) serta Kelurahan Pulau Tidung, Kelurahan Pulau Pari dan Kelurahan Pulau Untung Jawa ( Kecamatan Kepulauan Seribu Selatan).

\section{Identifikasi Masalah}

Pulau Tidung merupakan salah satu dari 3 pulau permukiman di Kabupaten Administrasi Kepulauan Seribu, Kecamatan Kepulauan Seribu Selatan. Selain berfungsi sebagai Pulau permukiman , Pulau Tidung juga merupakan destinasi wisata di Kepulauan Seribu. Jarak yang perlu ditempuh untuk ke Pulau Tidung yaitu sekitar 1-2 jam dengan menggunakan kapal dari DKI Jakarta ( Pelabuhan Muara Angke dan Ancol) membuat aksesibiltas ke pulau ini cukup baik. Pertumbuhan penduduk Pulau Tidung juga masih telatif rendah dan berpotensi untuk dikembangkan kegiatan wisata maupun kegiatan penduduk kedepannya. Namun yang menjadi sorotan adalah tidak adanya pengelolaan yang pasti mengenai kawasan wisata beserta fasilitasnya sehingga mengakibatkan kurangnya pelayanan yang diberikan. Selain itu akomodasiakomidasi yang ada juga tidak memiliki suatu standart pengelolaan sehingga terdapat perbedaan pelayanan yang diberikan dan tidak jarang berdampak buruk bagi kenyamanan wisatawan yang datang. Hal itu sangat berpengaruh negatif bagi sektor pariwisata di Pulau Tidung karena membuat wisatawan harus berpikir ulang untuk kembali datang ke Pulau ini mengingat kurangnya pelayanan akomodasi yang layak bagi para wisatawan baik lokal maupun mancanegara serta juga kurangnya pelayanan di tempat-tempat wisata maupun layanan dari fasilitas-fasilitas yang ada.

\section{Rumusan Masalah}

Berdasarkan identifikasi masalah diatas, maka rumusan masalah dalam penelitian ini adalah sebagai berikut :

1) Apakah terdapat standart/hal dasar dalam pengelolaan Pulau Kecil?

2) Apakah keberadaan sarana dan prasarana wisata yang ada sudah dapat melayani para wisatwan yang berkunjung ke Pulau Tidung dengan baik?

3) Apakah terdapat standart/hal dasar dalam pengelolaan akomodasi wisata khususnya di Pulau Kecil?

4) Apakah daya dukung kawasan Pulau Tidung cukup menampung kegiatan wisatawan yang ada dan yang akan datang?

5) Kebijakan apa yang seharusnya dilakukan untuk mengelola sarana dan prasarana yang sudah ada dan yang akan ada? 


\section{Ruang Lingkup Penelitian}

\section{Ruang Lingkup Teritorial}

Ruang Lingkup penelitian menurut teritorial adalah sebagai berikut :

a) Ruang Lingkup penelitan makro adalah Kabupaten Administrasi Kepulauan Seribu, Provinsi DKI Jakarta.

b) Ruang Lingkup penelitian mezzo adalah Kecamatan Kepulauan Seribu Selatan

c) Ruang Lingkup penelitian mikro adalah Kawasan Wisata Pulau Tidung Besar. (Peta 01. Peta Administratif Pulau Tidung Besar)

\section{Ruang Lingkup Substansial}

Ruang lingkup substansial dalam penelitian ini adalah pembahasan mengenai karakteristik lokasi wisata, pengelolaan kawasan wisata, karakteristik prasarana dan sarana pendukung wisata serta daya dukung sosial ekonomi dan daya dukung ekologis Pulau Tidung.

\section{Tujuan Penelitian}

Tujuan umum dalam penelitian ini adalah untuk melakukan pengelolaan kawasan wisata di Pulau Tidung besar sehinga dapat meningkatkan perekonomian di Pulau Tidung Besar. Sedangkan untuk Tujuan Khusus dari penelitian ini adalah:

1) Mengetahui pengelolaan eskisting Kawasan Wisata Pulau Tidung dan menemukan masalahmasalah utama terkait pengelolaan yang ada .

2) Mengetahui ketersediaan sarana-prasarana Kawasan Wisata Pulau Tidung untuk saat ini dan menemukan permasalahan terkait perkembangan sarana-prasarana yang ada dan yang akan ada.

3) Mengetahui aturan dasar/standart mengenai pengelolaan akomodasi wisata khusunya di Pulau Kecil dan menerapkan aturan dasar tersebut dalam akomodasi wisata Pulau Tidung Besar.

4) Mengetahui persepsi dan preferensi pengunjung mengenai pengelolaan Kawasan Wisata Pulau Tidung Besar.

5) Memberikan usulan strategi pengelolaan Kawasan Wisata Pulau Tidung.

\section{KAJIAN LITERATUR}

\section{Pengelolaan}

Pengelolaan (Prajudi Atmosudirjo, 1982) adalah suatu kegiatan pemanfaatan dan pengendalian atas semua sumber daya yang diperlukan untuk mencapai ataupun menyelesaikan tujuan tertentu.

Pengelolaan (Suharsimi Arikunto, 1993) diartikan sebagai suatu rangkaian pekerjaan atau usaha yang dilakukan oleh sekelompok orang untuk melakukan serangkain kerja dalam mencapai tujuan tertentu.

Dalam proses Pengelolaan atau manajemen (Nanang Fattah, 2004) melibatkan fungsi-fungsi pokok yang ditampilkan oleh seorang manajer atau pimpinan, yaitu perencanaan, pengorganisasian, pemimpin dan pengawasan. Oleh karena itu pengelolaan diartikan sebagai proses merencanakan, mengorganising, memimpin dan mengendalikan upaya organisasi dengan segala aspeknya agar tujuan organisasi tercapai secara efektif dan efisien.

\section{Pengelolaan Pulau Kecil}

Menurut, Kusumastanto (2000) menyatakan bahwa fokus utama dalam pengembangan kebijakan wisata bahari diarahkan ke:

1) Meningkatkan ketersediaan fasilitas dan layanan publik yang menciptakan kenyamanan tertinggi untuk domestik dan wisatawan asing yang akan memanfaatkan sumber daya wisata bahari. 
2) Meningkatkan kualitas dan kapasitas sumber daya manusia untuk ikut serta mengelola wisata bahari.

3) Mengembangkan sistem pengumpulan data dan melengkapi informasi dengan memanfaatkan teknologi modern, sehingga lebih mudah bagi wisatawan untuk mendapatkan informasi dan akses dengan cepat, murah dan mudah.

\section{METODE}

\section{Jenis Data}

Terdapat 2 Jenis data yang digunakan selama penelitian ini yaitu data primer dan data sekunder.

\section{Data Primer}

Data primer merupakan data yang didapatkkan dengan cara datang langsung mengamati visual dari objek penelitain. Pengumpulan data primer adalah sebagai berikut :

a) Kondisi fisik eksisting Pulau Tidung Besar, penggunaan lahan di Pulau Tidung Besar, data aksesibilitas untuk menuju ke Pulau Tidung Besar.

b) Wawancara langsung kepada pihak-pihak terkait yaitu Kepala Kelurahan Pulau Tidung dan masyarakat asli Pulau Tidung Besar serta Pemilik akomodasi wisata dan fasilitas wisata di Pulau Tidung Besar.

Data Sekunder

Data sekunder merupakan data di peroleh dari berbagai sumber yang relavan dengan objek penelitian, seperti buku-buku yang dipublikasi untuk masyarakat umum, jurnal, dokumen pemerintah serta data yang berasal dari intertet ( dapat dipertanggungjawabkan ke validasiya). Data yang diperoleh dari sekunder berupa :

a) Peraturan Kebijakan terkait dengan Pulau Tidung Besar

b) Laporan tahunan Kabupaten Kepulauan Seribu dan Kecamatan Kepulauan Seribu Selatan.

\section{Teknik Pengumpulan Data}

\section{Teknik Pengumpulan Data Primer}

Data Primer dapat berupa data kuantitatif dan Kualitatif. Berikut cara pengumpulan data primer :

1) Observasi Lapangan ( survei lapangan )

Observasi lapangan merupakan teknik dengan cara melihat langsung objek studi yang diteliti atau pengamatan secara langsung. Survei lapangan bertujuan untuk mengetahui bagaimana keadaan atau kondisi lapangan terkini dari objek yang diteliti yang dalam penelitian ini yaitu Pulau Tidung Besar.

2) Dokumentasi

Dokumentasi adalah metode dalam pengambilan data secara langsung namun hasil yang didapatkan berupa foto yang menggambarakan kondisi dari objek uyang diteliti dan dapat dipahami oleh masyarakat umum.

3) Wawancara

Wawancara merupakan cara untuk mengajukan pertanyaan dapat secara lisan kepada narasumber atau orang yang terkait yang memiliki hubungan dengan penelitain yang ssedag dilakukan.

4. Kuesioner

Kuesioner dilakukan untuk mendapatkan data yang lebih rinci yang tidak bisa didapa melalui wawancara yang diterjemahkan ke dalam bentuk item atau pertanyaan. Kuesioner disebarkan kepada responden yaitu pengunjung untuk mengetahui persepsi dan preferensi mengenai pengelolaan Kawasan Wisata Pulau Tidung. Lokasi dari penyebaran kuesioner yaitu di objek wisata hingga berada di kawasan penginapan/homestay. Waktu penyebaran kuesioner dilakukan pada hari kerja ataupun hari libur. Untuk menentukan jumlah sampel yang akan dijasikan responden dalam penelitian ini dilakukan dengan menggunakan rumus Slovin. 


\section{Teknik Pengumpulan Data Sekunder}

Dalam metode ini, data diperoleh melalaui perantara atau media. Data dapat berasal dari Pemerintah maupun non-pemerintah yang memilki keterkaitan dengan objek penelitian. Hasil yang didapatkan dari data sekunder ini berupa uraian, data angka dan peta mengenai objek penelitian.

\section{Metode Analisis dan Alat Analisis}

Terdapat beberapa metode analasis yang digunakan untuk mengolah data yang telah didapat, yaitu : Analisis Kebijakan ( Deskriptif dan SWOT ), Analisis Kondisi Fisik dan Pengelolaan Eksisting (Deskriptif dan SWOT ), Analisis Persebaran, Kondisi dan Pengelolaan Akomodasi Wisata ( Deskriptif dan SWOT ), Analisis Persepsi dan Preferensi Pengunjung (Crosstab, IPA, Deskriptif ), Anaslisis Daya Dukung Wisatawan ( Perhitungan daya dukung) , Analisi Rencana dan Strategi Konsep Pengelolaan ( Deskriptif dan SWOT).

\section{DISKUSI DAN HASIL}

\section{Analisis Kebijakan}

Dari segi kebijakan, pengelolaan pulau kecil didukung dengan adanya beberepa kebijakan yaitu :

Tabel 1 : Kebijakan yang mendukung Pengelolaan Pulau

\begin{tabular}{ll}
\hline Aspek & Kebijakan \\
\hline \multirow{2}{*}{ Sosial } & $\begin{array}{l}\text { Undang-Undang Republik Indonesia Nomor } 27 \text { Tahun } 2007 \text { Tentang } \\
\text { Pengelolaan Wilayah Pesisir dan Pulau-Pulau Kecil }\end{array}$ \\
\hline \multirow{2}{*}{ Pengelolaan } & $\begin{array}{l}\text { Peraturan Menteri Republik Indonesia No } 27 \text { tahun } 2015 \text { tentang } \\
\text { standar usaha Pengelolaan Objek Wisata }\end{array}$ \\
\hline \multirow{2}{*}{ Daya Dukung } & $\begin{array}{l}\text { Peraturan Menteri Negara Lingkungan Hidup Republik Indonesia } \\
\text { Nomor } 5 \text { thun } 2012 \text { tentang Jenis Rencana Usaha dan Kegiatan yang } \\
\text { wajib memiliki Analisis mengenai dampak Lingkungan Hidup }\end{array}$ \\
\hline \multirow{2}{*}{ Peruntukan } & $\begin{array}{l}\text { Peraturan Menteri Kelautan dan Perikanan Republik Indonesia No. } \\
\text { 23/Permen-Kp/2016 tentang Perencanaan Pengelolaan Wilayah } \\
\text { Pesisir dan Pulau-Pulau Kecil }\end{array}$ \\
\hline
\end{tabular}

Sumber: Penulis, 2019

Dari kebijakan-kebijakan tersebut dapat disimpulkan untuk mendukung pengelolaan Kawasan Wisata Pulau Tidung yaitu:

a. Pada Aspek pengelolaan Kawasan Wisata harus diperkuat dengan peran serta masyarakat dan lembaga pemerintah serta mendorong inisiatif masyarakat dalam pengelolaan sehingga meningkatkan nilai sosial, ekonomi dan budaya masyarakat melalui peran dari masyarakat pulau itu sendiri.

b. Pada aspek pemanfaatan ruang, setiap zona peruntukan yang ada haruslah memperhatikan wilayah masyarakat Hukum adat dan kearifan lokal di Kawasan Wisata Pulau Tidung

c. Kawasan Wisatan Pulau Tidung merupakan kawasan wisata yang dilengkapi dengan banyak akomodasi-akomodasi wisata yang keberadaannya haruslah diikuti dengan kajian analisis dampak lingkungan sehingga dapat diketahui ancaman atau dampak penting yang mungkin terjadi.

\section{Analisis Pengelolaan Pulau Kecil}

Sementara dari segi Pengelolaan eksisting Pulau, baik itu aspek lingkungan, ekonomi, sosial dan lingkup kerja operasional dijelaskan sebagai berikut: 
Tabel 2 : Pengelolaan Eksisting Kawasan Wisata Pulau TIdung

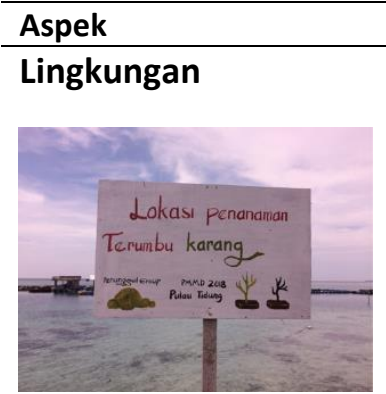

Gambar 1.Lokasi Penanaman Terumbu Karang Sumber: Penulis, 2019
1. Terumbu Karang yang ada di kelola swadaya oleh beberapa warga Pulau Tidung dengan arahan dari Suku Dinas Ketahanan Pangan, Kelautan dan Perikanan, Pemerintah Provinsi DKI Jakarta

2. Masih minimnya penyuluhan atas pentingkanya ekosistem terumbu karang bagi warga karena masih terdapat warga yang mengeksploitasi terumbu karang yang ada

3. Kawasan Agrowisata yang ada di lestarikan oleh warga dan warga yang ada merupakan pegawai honorer di Sudin setempat.

\section{Ekonomi}

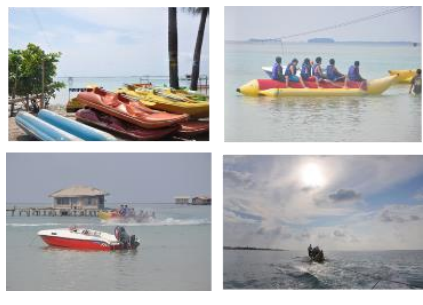

Gambar 2. Aktivitas Water Sport Sumber: Penulis, 2019
1. Terdapat 4 kegiatan ekonomi kreatif di Pulau Tidung, yaitu Kerajinan Tangan, makanan, Homestay dan jasa sewa peralatan atraksi wisata air 2. Tidak adanya komunitas kerajinan tangan di Pulau Tidung membuat hanya beberapa masyarakat saja yang menjadi pengrajin souvenir. Hal ini dapat menjadi ancaman untuk generasi yang akan datang karena minimnya kegiatan yang berfokus pada keterampilan yang dapat mengakibatkan semakin memudarnya kerajinan tangan yang ada.

3. Tidak adanya komunitas penggiat makannan dan jajanan pulau Tidung yang membuat hanya beberapa warga saja yang masih fokus menjajakan makanan asli daerah tersebut. Padahal potensi besar dimiliki dari sumber daya yang ada, seperti Buah sukun dan rumput laut.

4. Atraksi watersport merupakan salah satu peluang bagi warga karena dapat membuka lapangan pekerjaan baru dalam merawat dan menjaga alat-alat perlengkapan yang ada. Namun pentingnya sosialisai dan penyuluhan bagi warga akan bahanya kapal-kapal yang bersandar menggunakan jangkar besar serta minimnya penyuluhan terhadap instruktur snorkeling yang masih menyuruh wisatawan untuk berdiri diatas terumbu karang untuk mengambil gambar underwater.

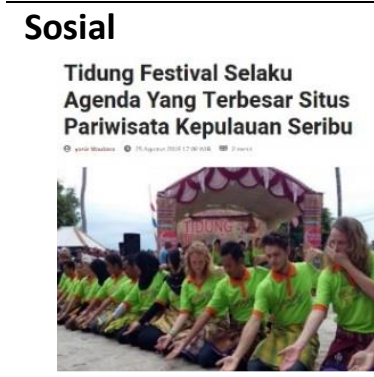

Gambar 3. Tidung Festival Sumber: berita pulau seribu, 2018

1. Sampai saat ini hanya terdapat 2 komunitas di Pulau Tidung, yaitu Komunitas Wanita Tani dan Komunitas Jejak seribu

2. Keberadaan kelompok wanita tani sangat berdampak positif karena membantu dalam proses percepatan penganekaragaman bahan pangan yang mana hal tersebut berdampak langsung pada masyarakat setempat.

3. Tidung Festival yang rutin di gelar setiap tahun sejak tahun 2012 berdampak positif karena bisa menarik wisatawan yang ada. Namun diperlukan kejelasan mengenai waktu yang tetap dalam penyelangggaraan Tidung Festival.

\begin{tabular}{ll}
\hline \multirow{2}{*}{ Promosi } & $\begin{array}{l}\text { 1. Promosi yang dilakukan hanya baru menggunakan website-website yang } \\
\text { dibuat oleh kelompok warga }\end{array}$ \\
& $\begin{array}{l}\text { 2. Promosi dilakukan dengan memberikan Paket wisata di website-websiter } \\
\text { tersebut. }\end{array}$ \\
\hline Lingkup Kerja Operasional & $\begin{array}{l}\text { Belum adanya lingkup pengelolaan yang pasti dari Kawasan Wisata baik itu } \\
\text { dari aspek organisasi, manajemen hingga sumber daya manusa yang ada }\end{array}$ \\
\hline
\end{tabular}

Sumber: Penulis, 2019

Dari tabel diatas dapa dilihat bahwa belum adanya lingkup pengelolaan yang pasti dari Kawasan Wisata baik itu dari aspek organisasi, manajemen hingga sumber daya manusa yang ada. Hal ini terjadi karena tidak adanya SOP yang jelas dan terperinci. Selain itu masih kurangnya tenaga Sumber Daya Manusia (SDM) yang handal untuk bagian operasional yaitu staff yang melayani di Kawasan Wisata Pulau Tidung. Hal ini harus menjadi perhatian khusus karena lingkup kerja operasional sangat diperlukan untuk memberikan jaminan kualiatas pelayanan bagi wiatawan yang berkunjung. 


\section{Analisis Akomodasi Wisata}

Sementara itu, akomodasi wisata merupakan kegiatan ekonomi kreatif yang paling menonjol dari Kawasan Wisata Pulau Tidung. Ketersediaan Homestay yang banyak membuat wisatawan memilki banyak opsi selama menginap di Pulau ini. Namun masih terdapat kekurangan dari segi pengelolaan hingga pelayanan yang diberikan, berikut hasil analisis yang ada:

Berdasarkan analisa yang ada terdapat 3 pusat persebaran penginapan yaitu : Penginapan di bagian selatan Pulau dengan view laut, Penginapan di tengah permukiman warga serta, Penginapan di bagian Utara Pulau dengan view laut dengan suasana kegiatan nelayan. Ketiganya memiliki nuansa penginapan yang berbeda sehingga menjadi alternaif pilihan bagi wisatawan yang berkunjung ke Pulau Tidung Besar.

Selain itu kondisi akomodasi yang ada telah disandingankan dengan ASEAN Tourism Strategic Plan 2011-2015 mengenai kriteria yang harus dipenuhi dalam mengelola akomodasi wisata diantaranya: Penyedia Akomodasi, Kesiapan Akomodasi, Kegiatan yang ada, Pengelola, Kebersihan dan Kerapihan serta Keamanan. Aspek-aspek tersebut telah dipenuhi oleh homestay-homestay yang ada walaupun terdapat terdapat beberapa kekurangan.

Sampai dengan saat ini akomodasi-akodamodasi yang ada di Pulau Tidung tidak memiliki sistem pengelolaan yang jelas. Akomodasi yang ada dikelola perorangan tanpa ada standart umum dalam manajemen pengelolaannya. Sehingga kadang, pelayanan yang diberikan tidak memuaskan para wisatawan dan hal ini menjadi masalah yang cukup serius wisatawan akan berpikir ulang untuk kembali ke Pulau Tidung karena minimnya kenyamanan selama berada di Pulau Tidung khususnya selama menginap di Homestay yang ada.

Standar Pengelolaan diperlukan untuk menjaga kualitas penginapan agar dapat menarik hati wisatawan untuk kembali berkunjung ke Pulau Tidung dan menginap di Homestay-homestay warga yang ada. Dalam hal pengelolaan akomodasi wisata khususnya di Pulau Kecil dibutuhkan terobosan yang signifikan guna meningkatkan kualitas akomodasi itu sendiri. Terobosan yang ada haruslah mengikuti tren perkembangan yang ada khususnya dibidang informasi dan teknologi. Sampai dengan saat teknologi merupakan jawaban dalam hal pengelolaan suatu akomodasi wisata guna memaksimalkan fungsi yang ada. Virtuhal Hotel Operator merupakan bisnis yang lahir dengan akomodasi sebagai bahan jualan utama yang disejalankan dengan kecanggihan teknologi.

\section{Virtual Hotel Operator}

Virtual Hotel Operator : Konsep bisnis yang menyewa janga panjang kamar-kamar hotel dari mitranya, kemudian kamar-kamar ini ditawarkan kembali kepada traveler dengan merk/atribut meraka sendiri. Pada dasarnya, perusahaan tersebut tidak punya properti, semua kamar yang ada merupakan kamar mitra yang di sewa dalam jangka panjang, yang kemudian di kamar-kamar tersebut difasilitasi dengan standar yang telah dibuat masing-masing perusahaan. VHO menjual kamar di website mereka sendiri dan melakukan manajemen hotel untuk memastikan standart tetap terjaga. Berbeda dengan OTA ( Online Travel Agent ), OTA hanya sebagai tempat memesan kamar saja tanpa ada manajemen hotel dari pemiliki OTA, contohnya: Traveloka, booking.com, dll.

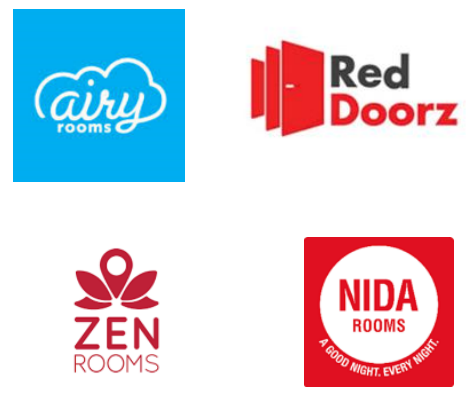

1. Airi Rooms (Solusi Budget Travel)

2. Red Doorz (Standardised Budget Accommodation)

3. Zen Rooms (Travel More, Pay Les)

4. Nida Rooms (Branded Hotel Room Network) 
Dari ke-4 VHO yang ada diperoleh beberapa standart yang harus dipenuhi oleh suatu akomodasi jika ingin menjalankan kerja sama ke-4 VHO tersebut. Berikut 6 standart akomodasi yang harus dipenuhi: 1. Akses internet gratis/Wifi, 2. TV , 3. Pendingin Ruangan/AC, 4. Peralatan Alat Mandi, 5.Tempat tidur yang bersih dan nyaman, 6. Menyediakan Air Mineral Gratis.

Jika dilihat dari kondisi akomodasi yang ada di Pulau Tidung, beberapa kewajiban penyedia akomodasi telah terpenuhi dan memungkinkan untuk bekerja sama dengan Perusahan VHO yang ada. Namun untuk sampai saat ini, dari ke 4 VHO yang ada belum ada rencana untuk mengembangkan bisnisnya ke Pulau-pulau kecil karena masih berfokus ke kota-kota besar. Namun hal itu tidak menutup kemungkinan dalam beberapa waktu kedapan, kerjasama yang ada dapat terajalin mengingat sebagian besar kewajiban telah dapat dipenuhi oleh penyedia homestay, seperti : Pendingin ruangan, TV, kasur yang bersih dan nyaman, air mineral gratis dan peralatan alat mandi.

Namun, minimnya akses internet gratis yang diberikan oleh penyedia akomodasi saat ini, yang mana akses internet merupakan kewajiban utama yang harus disediakan, membuat terhambatnya kerjasama antara pihak penyedia homestay dan Perusahaan VHO yang ada. Kerjasama dengan Kementrian PUPR dengan Program BSPS (Bantuan Stimulan Perumahan Swadaya) diharapkan dapat memebantu penyedia homestay dalam meningkatkan kualitas interior akomodasi sehingga sesuai standart yang ada.

Selain itu Program Pemerintah Daerah yaitu menjadikan Pulau Tidung sebagai Pulau Digital juga diharapkan menjadi jawaban atas masalah ketersediaan jaringan di internet yang ada. Dengan berjalannya program Pulau Digital semakin terbukanya peluang sistem manajemen online akomodasi yang ada, bekerjasma dengan Perusahaan VHO .Dengan begitu, pengelolaan secara fisik dan pengelolaan secara online dapat berjalan beriringan sehinga meningkatkan kualitas akomodasi di Kawasan Wisata Pulau Tidung

\section{Analisis Persepsi dan Preferensi Pengunjung}

Berdasarkan dari hasil olahan kuesioner yang telah disebar, analisis persepsi dan preferensi pengunjung bahwa didapat kesimpulan yang akan dijelaskan pada tabel di bawah ini.

Tabel 3. Kesimpulan Analisis Persepi dan Preferensi Pengunjung

\begin{tabular}{|c|c|}
\hline Aspek & Kesimpulan \\
\hline \multirow{7}{*}{$\begin{array}{l}\text { Karakteristik } \\
\text { Pengunjung }\end{array}$} & Sebanyak $45 \%$ pengunjung berusia 18-29 tahun dan belum menikah \\
\hline & Sebanyak 59\% pengunjung berasal dari Jakarta \\
\hline & $\begin{array}{l}\text { Sebanyak } 38 \% \text { Pengunjung merupakan Karyawan swasta dengan pendapatan } \\
4 \text { juta - } 6 \text { Juta }\end{array}$ \\
\hline & Sebanyak 53 \% pengunjung datang untuk melihat keindahan alam \\
\hline & Sebanyak $48 \%$ pengunjung telah datang ke Pulau Tidung seabnyak 2 kali \\
\hline & Sebanyak $94 \%$ pengunjung menginap $2-3$ hari \\
\hline & Sebanyak $54 \%$ pengunjung datang dengan teman \\
\hline \multirow{2}{*}{$\begin{array}{l}\text { Tingkat Kepuasan } \\
\text { dan Kepentingan } \\
\text { Pengunjung }\end{array}$} & $\begin{array}{l}\text { Terdapat } 7 \text { aspek yang harus ditingkatkan secara prioritas menurut pengunjung } \\
\text { yaitu Jalan menuju dermaga Kali Adem, Ketersediaan pusat infomasi, } \\
\text { Kebersihan penginapan, Ketersediaan Tempat makan, Ketersediaan toko } \\
\text { souvenir, Fasilitas Penginapan yang ditawaran (Misal: TV, Kaca, alat mandi dll), } \\
\text { serta Kebersihan Kamar Mandi ( Penginapan ). Apabila hal tersebut } \\
\text { ditingkatkan akan meningkatkan kepuasan pengunjung dan merasa puas } \\
\text { dengan pelayanan di Kawasan Wisata Pulau Tidung. }\end{array}$ \\
\hline & $\begin{array}{l}\text { Terdapat } 9 \text { aspek yang mempengaruhi tingkat kepuasan yang sudah baik yaitu: } \\
\text { Ketersediaan transportasi menuju Pulau Tidung, Ketersediaan loket tiket, } \\
\text { Ketersediaan papan petunjuk informasi/petunjuk jalan, Ketersediaan tempat } \\
\text { ibadah, Ketersediaan pos keamanan, Ketersediaan toilet umum, Kebersihan } \\
\text { toilet umum, Staf yang sopan dan ramah, Kebersihan Penyajian Makanan. Hal } \\
\text { tersebut perlu dipertahankan agar kepuasan pengunjung tetap terjaga. }\end{array}$ \\
\hline
\end{tabular}




\begin{tabular}{ll}
\hline \multicolumn{1}{c}{ Aspek } & \multicolumn{1}{c}{ Kesimpulan } \\
\hline & $\begin{array}{l}\text { Sebanyak 84\% pengunjung menyarankan untuk melakukan promosi melalui } \\
\text { media yaitu media sosial }\end{array}$ \\
\cline { 2 - 2 } & $\begin{array}{l}\text { Pengunjung menyarankan agar terdapat penambahan tempat-tempat makan } \\
\text { beserta menu makanan yang baru serta harga yang terjangkau. }\end{array}$ \\
\cline { 2 - 2 } Preferensi & $\begin{array}{l}\text { Pengunjung menyarankan agar terdapat penambahan pusat-pusat informasi } \\
\text { Pengunjung }\end{array}$ \\
\cline { 2 - 2 } & beserta dengan petugas yang berjaga \\
\hline
\end{tabular}

Pengunjung menyarankan agar terdapat penambahan toko-toko souvenir

Sumber : Penulis, 2019

\section{Rencana Pengelolaan Kawasan Wisata Pulau Tidung}

Rencana mendasar dalam meningkatkan pengelolaan yang ada adalah dengan membangun lingkup kerja operasional di Kawasan Wisata Pulau tidung berdasarkan standart Peraturan Menteri Pariwisata no. 27 Tahun 2015 tentang pengelolaan tempat wisata. Usulan strategi yang ada yaitu:

Tabel 4. Rencana Manajemen Operasional

\begin{tabular}{|c|c|c|}
\hline Unsur & Sub Unsur & Usulan \\
\hline \multirow{6}{*}{ Organisasi } & \multicolumn{2}{|l|}{ 1. Profil usaha yang terdiri atas: } \\
\hline & $\begin{array}{l}\text { a. Struktur organisasi yang lengkap dan } \\
\text { terdokumentasi }\end{array}$ & $\begin{array}{l}\text { Membuat suatu struktur organisasi } \\
\text { yang melibatkan masyarakat- } \\
\text { mayaralat sebagai anggota atau } \\
\text { bahkan Kepala Bagian. }\end{array}$ \\
\hline & $\begin{array}{l}\text { b. Uraian tugas dan fungsi yang lengkap } \\
\text { setiap jabatan dan terdokumentasi }\end{array}$ & $\begin{array}{l}\text { Membuat jobdesk masing-masing } \\
\text { divisi sesuai dengan lingkup kerja yang } \\
\text { ada. }\end{array}$ \\
\hline & $\begin{array}{l}\text { 2. Rencana usaha yang lengkap, terukur dan } \\
\text { terdokumentasi }\end{array}$ & $\begin{array}{l}\text { Membuat rencana kerja dalam jangka } \\
\text { panjang maupun jangka pendek. }\end{array}$ \\
\hline & $\begin{array}{l}\text { 3. Dokumen prosedur operasional standar } \\
\text { (Standard Operating Prosedure) dan/atau } \\
\text { petunjung pelaksanaan kerja }\end{array}$ & $\begin{array}{l}\text { Membuat suatu standart operating } \\
\text { prosedure yang sesuai dengan } \\
\text { karaktertistik Pulau Tidung. }\end{array}$ \\
\hline & $\begin{array}{l}\text { 4. Peraturan perusahaan atau perjanjian } \\
\text { kerja bersama sesuai dengan ketentuan } \\
\text { peraturan perundang-undangan dan } \\
\text { terdokumentasi }\end{array}$ & $\begin{array}{l}\text { Membuat suatu peraturan terkait } \\
\text { perjanjian kerjasama yang didisuaikan } \\
\text { dengan kondisi Pulau Tidung. }\end{array}$ \\
\hline \multirow{5}{*}{ Manajemen } & $\begin{array}{l}\text { Pelaksanaan program pemeliharaan dan } \\
\text { penyimpanan dokumen kegiatan usaha }\end{array}$ & $\begin{array}{l}\text { Membuat suatu sistem database } \\
\text { terkait dengan program dan } \\
\text { pemeliharan yang dilakukan. }\end{array}$ \\
\hline & $\begin{array}{l}\text { Pelaksanaan program kebersihan dan } \\
\text { perawatan lingkungan }\end{array}$ & $\begin{array}{l}\text { Mempertahankan kerja sama dengan } \\
\text { masyarakat dan petugas kebersihan } \\
\text { dari kelurahan }\end{array}$ \\
\hline & $\begin{array}{l}\text { Pelaksanaan program pencegahan dan } \\
\text { penanggulangan kebakaran, atau dalam } \\
\text { keadaan darurat sesuai dengan ketentuan } \\
\text { peraturan perundang-undangan }\end{array}$ & $\begin{array}{l}\text { Membuat program penyuluhan } \\
\text { tentang } \\
\text { Siaga tsunami. }\end{array}$ \\
\hline & $\begin{array}{l}\text { Pelaksanaan program keselamatan dan } \\
\text { kesehatan kerja (K3) yang disusun secara } \\
\text { lengkap dan terdokumentasi }\end{array}$ & $\begin{array}{l}\text { Mengadakan program keselamatan } \\
\text { dan kesehatan kerja dengan dinas } \\
\text { terkait. }\end{array}$ \\
\hline & $\begin{array}{l}\text { Pelaksanaan program pengawasan ramah } \\
\text { lingkungan yang mengikuti kaidah } \\
\text { konservasi dan pelestarian lingkungan } \\
\text { sesuai dengan standar dan/atau }\end{array}$ & $\begin{array}{l}\text { Membuat program Konservasi } \\
\text { Terumbu karang bekerjasama dengan } \\
\text { Kelompok Pemuda yang ada di Pulau } \\
\text { Tidung. }\end{array}$ \\
\hline
\end{tabular}




\begin{tabular}{|c|c|c|}
\hline Unsur & Sub Unsur & Usulan \\
\hline & $\begin{array}{l}\text { ketentuan peraturan, perundang- } \\
\text { undangan, dan terdokumentasi }\end{array}$ & \\
\hline & $\begin{array}{l}\text { Tersedian tempat penampungan } \\
\text { sementara sampah organik dan non- } \\
\text { organik }\end{array}$ & $\begin{array}{l}\text { Mempertahankan tempat } \\
\text { penampungan sementara sampah } \\
\text { organik dan non organic yang ada. }\end{array}$ \\
\hline & $\begin{array}{l}\text { Tersedia perlengkapan pertolongan } \\
\text { pertama pada kecelakaan ( } \mathrm{p} 3 \mathrm{k} \text { ) sesuai } \\
\text { dengan standar dan/atau ketentuan } \\
\text { peraturan perundang-undangan }\end{array}$ & $\begin{array}{l}\text { Menambah perlengkapan pertolongan } \\
\text { pertama di objek-objek wisata seperti } \\
\text { di sekitaran Jembatan Cinta dan Pulau } \\
\text { Tidung Kecil. }\end{array}$ \\
\hline \multirow{5}{*}{$\begin{array}{l}\text { Sumber } \\
\text { Daya } \\
\text { Manusia }\end{array}$} & $\begin{array}{l}\text { Melaksanakan sertifikasi kompetisi sesuai } \\
\text { dengan kebutuhan }\end{array}$ & $\begin{array}{l}\text { Bekerjasa sama dengan lembaga } \\
\text { sertifikasi yang ada sehinga } \\
\text { sumberdaya manusia yang ada } \\
\text { diberikan penyuluhan serta } \\
\text { kompetensi sesuai dengan keadaan di } \\
\text { Pulau Kecil. }\end{array}$ \\
\hline & Melaksanakan evaluasi kinerja SDM & $\begin{array}{l}\text { Membuat suatu tes untuk menguji } \\
\text { keterampilan dan pengetahuan setiap } \\
2 / 3 \text { bulan sekali. }\end{array}$ \\
\hline & $\begin{array}{l}\text { Melaksanakan pemeriksaan kesehatan } \\
\text { berkala untuk karyawan }\end{array}$ & $\begin{array}{l}\text { Bekerja sama dengan pihak puskesmas } \\
\text { Kecamatan Pulau Tidung untuk } \\
\text { pemeriksaan rutin bagi setiap staff } \\
\text { yang ada. }\end{array}$ \\
\hline & $\begin{array}{l}\text { Pengamanan oleh satuan petugas } \\
\text { keamanan }\end{array}$ & $\begin{array}{l}\text { Mempertahankan petugas keamanan } \\
\text { yang ada serta membuat jadwal } \\
\text { keliling rutin setiap personil keamanan } \\
\text { yang ada. }\end{array}$ \\
\hline & $\begin{array}{l}\text { Pengawas keselamatan pengunjung yang } \\
\text { berkualitas }\end{array}$ & $\begin{array}{l}\text { Memperbanyak pos-pos penjagaan } \\
\text { dititik-titik objek vital Pulau dalam hal } \\
\text { ini kasawan Jembatan Cinta. }\end{array}$ \\
\hline
\end{tabular}

Sumber : Penulis, 2019

Untuk menjaga Kawasan Wisata Pulau tidung dari segi aspek lingkungan, ekonomi dan sosial diperlukan sebuah rencana dan strategi dari pengelolaan yang ada. Rencana dan strategi tersebut dijelaskan, sebagai berikut:

Tabel 5. Rencana Pengelolaan terkait aspek Lingkungan, Ekonomi dan Sosial

\begin{tabular}{|c|c|c|}
\hline Aspek & Rencana & Strategi \\
\hline Lingkungan & $\begin{array}{l}\text { 1. Melakukan penyuluhan yang } \\
\text { berkelanjutan kedapa warga asli Pulau } \\
\text { mengenai pentingnya ekosistem Terumbu } \\
\text { Karang, } \\
\text { 2. Bekerjasama dengan pihak travel wisata } \\
\text { Pulau Tidung, agar setiap wisatawan yang } \\
\text { datang menggunakan travel yang ada } \\
\text { diwajibkan untuk melakukan penanaman } \\
\text { terumbu karang. } \\
\text { 3. Mengadakan sosialisai dan penyuluhan } \\
\text { bagi warga akan bahanya kapal-kapal yang } \\
\text { bersandar menggunakan jangkar besar } \\
\text { serta } \\
\text { 4. Penyuluhan terhadap instruktur } \\
\text { snorkeling yang masih menyuruh } \\
\text { wisatawan untuk berdiri diatas terumbu }\end{array}$ & $\begin{array}{l}\text { 1. Penyuluhan yang ada dapat } \\
\text { dilakukan bekerjasama dengan } \\
\text { Yayasan Terumbu Karang Indonesia( } \\
\text { Terangi) dengan mengadakan } \\
\text { program terkait kelestarian terumbu } \\
\text { karang. } \\
\text { 2. Memasukkan program penanaman } \\
\text { terumbu karang di setiap paket } \\
\text { wisata sehingga setiap wisatawan } \\
\text { yang ada berkontribusi dalam } \\
\text { menjaga Kelestarian Laut yang ada. }\end{array}$ \\
\hline
\end{tabular}




\begin{tabular}{|c|c|c|}
\hline Aspek & Rencana & Strategi \\
\hline & $\begin{array}{l}\text { karang untuk mengambil gambar } \\
\text { underwater. }\end{array}$ & \\
\hline Ekonomi & $\begin{array}{l}\text { 1.Mengadakan Penyuluhan dan sosialisasi } \\
\text { tentang penting pelestarian kerajinan } \\
\text { tangan dan jajanan lokal. } \\
2 \text { Membuat Komunitas Kerajinan Tangan } \\
\text { 3. Membuat Komunitas Jajajan Lokal. }\end{array}$ & $\begin{array}{l}\text { 1. Melibatkan Anak-anak muda dan } \\
\text { pengrajin souvenir terdahulu yang } \\
\text { ada di Pulau Tidung. } \\
\text { 2. Menjalin kerjasama dengan } \\
\text { Komunitas Jejak Seribu agar menjadi } \\
\text { bagian dari progaram rencana } \\
\text { kegitan rutin. }\end{array}$ \\
\hline Sosial & $\begin{array}{l}\text { 1. Membuat komunitas-komunitas baru } \\
\text { seperti : Komunitas Instruktur Snorkling, } \\
\text { Komunitas Nelayan. } \\
\text { 2. Membuat event Tidung Festival di waktu } \\
\text { yang sama di setiap tahun yaitu di } \\
\text { Pertengahan Tahun. Karena waktu ini } \\
\text { adalah waktu yang pas yaitu jauh dari } \\
\text { musim penghujan dan merupakan musim } \\
\text { liburan bagi anak-anak sekolah. }\end{array}$ & $\begin{array}{l}\text { 1. Mengumpulkan dan memberikan } \\
\text { penyuluhan kepada setiap nelayan } \\
\text { dan instruktur snorkling tenatang } \\
\text { pentingnya komunitas untuk menjaga } \\
\text { keberlangsungan yang ada. } \\
\text { 2.Melibatkan setiap Komunitas dalam } \\
\text { kegiatan Pulau Tidung Festival } \\
\text { sehingga itu merupakan wadah } \\
\text { mereka untuk menyalurkan hasil- } \\
\text { hasil pelatihan mereka selama ini }\end{array}$ \\
\hline
\end{tabular}

Sumber : Penulis, 2019

Dengan terjalinnya Program-Program pemerintah yang ada seperti Pulau Digital dan Program BSPS Kementrian PUPR diharapkan dapat meningkatkan standart kualitas penyedia akomodasi yang ada kedapannya. Serta keberadaan VHO juga diharapkan dapat meningkatkan tingkat hunian akomodasi yang ada melalui promosi yang ada media elektronik. Namun hal itu harus didahului dengan sebuah sistem pengelolaan akomodasi di Pulau itu sendiri agar terdapat standat dan acuan khusus dalam menjalan suatu usaha akomodasi. Berikut Rencana Pengelolaan Akomodasi di Pulau Tidung :

Tabel 6. Rencana Pengelolaan Akomodasi

\begin{tabular}{|c|c|c|}
\hline Aspek & Rencana & Strategi \\
\hline Organisasi & $\begin{array}{l}\text { 1. Membuat organisasi beserta } \\
\text { dengan struktur yang sistematis } \\
\text { serta penjelasan peran, } \\
\text { tanggung jawab dan jalur } \\
\text { komunikasi yang ada. }\end{array}$ & $\begin{array}{l}\text { 1. Mewajibkan dan melibatkan setiap penyedia } \\
\text { homestay untuk bergabung dalam organisasi ini. }\end{array}$ \\
\hline \multirow[t]{2}{*}{ Database } & $\begin{array}{l}\text { 1. Membuat Homestay } \\
\text { Operator Database }\end{array}$ & $\begin{array}{l}\text { 1. Membuat database yang berisi informasi } \\
\text { seperti: } \\
\text { a. Alamat Rumah } \\
\text { b. Jumlah Anggota Keluarga } \\
\text { c. Ketrampilan dan bakat khusus setiap anggota } \\
\text { keluarga }\end{array}$ \\
\hline & $\begin{array}{l}\text { 2. Membuat Database } \\
\text { Pengunjung }\end{array}$ & $\begin{array}{l}\text { 1. Mencatat dan menimpan informasi wisatawan, } \\
\text { seperti: } \\
\text { a. Jenis Kelamin } \\
\text { b. Usia } \\
\text { c. Status } \\
\text { d. Tempat Tinggal } \\
\text { e. Jenis pekerjaan } \\
\text { f. Durasi tinggal di Homestay } \\
\text { 2. Mencatat dan menyimpan komentar, keluhan } \\
\text { dan saran pengunjung }\end{array}$ \\
\hline
\end{tabular}




\begin{tabular}{|c|c|c|}
\hline Aspek & Rencana & Strategi \\
\hline & $\begin{array}{l}\text { 3. Membuat Database Produk } \\
\text { Wisata }\end{array}$ & $\begin{array}{l}\text { 1. Melakukan pembaruan sumber daya wisata } \\
\text { yang ada di Pulau Tidung }\end{array}$ \\
\hline Pelatihan & $\begin{array}{l}\text { 3. Mengadakan bagi setiap } \\
\text { anggota penyedia homestay }\end{array}$ & $\begin{array}{l}\text { 1. Membuat pedoman yang sederhana yang } \\
\text { meliputi aspek berikut : } \\
\text { a. . Menyambut dan melayani tamu } \\
\text { b. Pendaftaran, penagihan dan pembayaran } \\
\text { c. Kebersihan dan Keamanan } \\
\text { d. Keterampilan komunikasi ( Bahasa Inggris) } \\
\text { e. Perencanaan, mengorganisir dan menangani } \\
\text { kegiatan } \\
\text { f. Pemasaran dan promosi } \\
\text { g. Keteramplan bercerita dan interpretasi }\end{array}$ \\
\hline Kerjasama & $\begin{array}{l}\text { 4. Membangun Kerjasama } \\
\text { dengan berbagai pihak }\end{array}$ & $\begin{array}{l}\text { 1. Mengadakan Kerja sama dengan Virtual Hotel } \\
\text { Operator } \\
\text { 2. Lembaga-lembaga publik seperti Organisasi } \\
\text { Pariwisata Nasional dan Internasional untuk } \\
\text { meminta bantuan dalam hal pelatihan, } \\
\text { pendanaan, pemasaran dan promosi dan saran } \\
\text { teknis lainnya. } \\
\text { 3. Organisasi non-pemerintah (LSM) untuk } \\
\text { mengembangkan program-program bersama di } \\
\text { lingkungan konservasi dan pelestarian budaya. } \\
\text { 4. Universitas dan institusi pendidikan tinggi untuk } \\
\text { nasehat teknis dan pelatihan. }\end{array}$ \\
\hline
\end{tabular}

\section{KESIMPULAN DAN SARAN}

Dari setiap analisis yang ada diperoleh beberapa kesimpulan, yaitu:

a) Kawasan Wisata Pulau Tidung merupakan objek wisata alam di Kepulauan Seribu yang memiliki berbagai jenis kegiatan wisata diantaranya : Pantai Pasir Putih, Atraksi Wisata Air di sekitar Jembatan Cinta, Konservasi Terumbu Karang serta Mangrove yang berkonsepkan agrowisata serta dilengkapi dengan banyaknya penginapan-penginapan yang tersedia. Selain itu, lokasi yang cukup strategis serta memiliki akses yang mudah dan berbagai alternatif moda transportasi merupakan daya tarik tambahan untuk wisatawan berkunjung.

b) Dilihat dari sisi kebijakan, Pulau Tidung sebenarnya telah didukung dengan beberapa kebijakan penting diantaranya Peraturan Menteri Republik Indonesia No 27 tahun 2015 tentang standar usaha Pengelolaan Objek Wisata yang merupakan modal awal dalam pengelolaan Kawasan Wisata Pulau Tidung agar menjadi lebih baik lagi. Selain itu programprogram pemerintah seperti Pulau Digital yang di rencanakan oleh Dinas Provinsi DKI Jakarta dan Otoritas Jasa Keuangan dapat menjadi solusi untuk manjemen pengelolaan yang berbasiskan teknologi informasi. Selain itu, program Bantuan Stimulan Perumahan Swadaya (BSPS) dapat menjadi solus dalam meningkatkan kualitas homestay-homestay warga yang ada.

c) Berdasarkan analisis persepsi dan preferensi pengunjung, diperlukan perbaikan maupun penambahan fasilitas seperti, Pusat informasi di dermaga Pulau Tidung, ketersedian tempat makan dan menu makanan, ketersedian toko souvenir hingga fasilitas dan kebersihan kamar dan kamar mandi di tempat penginapan yang ada. Selain itu pengunjung juga menyarakankan promosi Kawasan Wisata Pulau Tidung dilakukan dengan menggunakan Sosial Media.

d) Daya tampung wisatawan di objek-objek wisata tidung telah dapat menampung wisatawan berkunjung pada hari sabtu dan minggu serta libur nasional. Dari pihak dermaga sendiri tidak melakukan pembatasan pengunjung, namun jika hal itu dibiarkan, kedepaanya ditakutkan terjadi kerusakan di objek-objek wisata khususnya di sekitar Kawasan Jemabatan Cinta. 
e) Masih belum adanya sistem pengelolaan yang pasti beserta lingkup kerja opersional merupakan masalah utama dalam Kawasan Wisata Pulau tidung. Masih minimnya keterlibatan masyrakat juga merupakan hal yang perlu diperhatikan agar pengelolaan pulau dapat diselaraskan dengan kehidupan warga pulau.

f) Dengan terwujudnya rencana strategi yang ada yaitu: Rencana Manajemen Operasional, Rencana Pengelolaan Fasilitas Fasilitas, Rencana dan Strategi terkait aspek lingkungan, ekonomi dan sosial serta Rencana Pengelolaan Akomodasi wisata yang ada di Pulau Tidung, diharapakan dapat meningkatkan skala pelayanan yang ada, sehingga pengunjung yang datang ke Pulau Tidung merasa aman dan nyaman selama beraktivitas di Pulau dan memilki keinginan kembali untuk datang ke Pulau ini dilain kesempatan.

\section{Saran}

Bagi Pemerintah

a) Membentuk suatu tim Pengelola Kawasan Pulau Tidung yang melibatkan warga pulau tidung didalam jajaran pengelolanya.

b) Menjalankan program Pulau Digital dapat segera terlaksanakan sehingga masalah keterbatasan internet di Kawasan Pulau Tidung dapat teratasi.

c) Menjalankan program Bantuan Stimulan Perumahan Swadaya dapat segera terlaksanakan sehingga dapat meningkatkan kualitas penginapan yang ada di Pulau Tidung.

d) Mengadakan program pemugaran terhadap fasilitas-fasilitas penunjang kawasan wisata serta memberikan penyuluhan dan sosialisasi kepada masyarakat pulau dalam hal merawat fasilitas-fasilitas penunjang yang ada.

e) Mengawasi setiap kebijakan yang ada khususnya jika masuknya Virtual Hotel Operator kedalam manajemen pengelolaan akomodasi wisata di Pulau Tidung.

\section{Bagi Masyarakat}

a) Dapat bekerjasama dengan Pemerintah dalam menjalankan program-program yang ada.

b) Menjaga keberadaan komunitas yang sudah ada dan mengembangkan lagi komunitaskomunitas baru yang dapat meningkatkan kualiatas lingkungan, ekonomi dan nilai sosial Kawaasan Wisata Pulau Tidung

\section{Bagi Pengunjung}

a) Dapat menaati peraturan yang ada di Kawasa Wisata Pulau Tidung dan menjaga kebersihan lingkungan baik daratan maupun lautan sehingga tetap terjaga kelestariannya.

\section{REFERENSI}

Atmosudirjo, P. (1982). Administrasi dan Manajemen Umum. Jakarta: Ghalia Indonesia.

Arikunto, S. (1993). Manjemen Penelitian. Jakarta: PT. Raja Grafindo. Persada.

ASEAN Tourism Strategic Plan (ATSP):2011-2015

Creswell, J. W. (1998). Qualitative Inquiry and Research Design, Choosing Among Five Traditions. California: Sage Publication.

Dahl, A. L. (2006). Small Island Environmet Management. Swiss : UNEP Eartwatch

Fattah, N. (2004). Konsep Manajemen Berbasis Sekolah (MBS) dan Dewan. Sekolah. Bandung: CV Pustaka Bani Quraisy

Kusumastanto, T. (2000). Pengembangan Sumber Daya kelautan dalam memperkokoh Perekonomian Nasional Abad 21. Kajian Ekonomi. Kelautan. IPB.

Martilla, J.A. and James, J.C. (1977) Importance-Performance Analysis. Journal of Marketing, 41, 77-79.

Pitana, I.G. ,Diarta, I.K.S. (2009). Pengantar IImu Pariwisata. Yogyakarta: C.V Andi Offset.

Supranto, J. (1997). Pengukuran Tingkat Kepuasan Konsumen. Jakarta : Rineka Cipta. Hal. 242 
